\title{
Influence of environmental quality of the tributaries of the Monjolinho River on the relative condition factor $(\mathrm{Kn})$ of the local ichthyofauna
}

\author{
Germano Henrique Costa Barrilli ${ }^{1,4}$, Odete Rocha ${ }^{2}$, Natalia Felix Negreiros ${ }^{1} \&$ José Roberto Verani $^{3}$ \\ ${ }^{1}$ Programa de Pós-graduação em Ecologia e Recursos Naturais, Universidade Federal de São Carlos, \\ Rodovia Washington Luis, km 235, CEP 12565-905, São Carlos, SP, Brazil. \\ ${ }^{2}$ Departamento de Ecologia e Biologia Evolutiva, Universidade Federal de São Carlos, Rodovia Washington \\ Luis, km 235, CEP 13565-905, São Carlos, SP, Brazil. \\ ${ }^{3}$ Departamento de Hidrobiologia, Universidade Federal de São Carlos, Rodovia Washington Luis, km 235, \\ CEP 13565-905, São Carlos, SP, Brazil. \\ ${ }^{4}$ Corresponding author: Germano Henrique Costa Barrilli, e-mail: germanohcb@msn.com
}

BARRILLI, G.H.C, ROCHA, O., NEGREIROS, N.F., VERANI, J.R. Influence of environmental quality of the tributaries of the Monjolinho River on the relative condition factor (Kn) of the local ichthyofauna. Biota Neotropica. 15(1): e20140107. http://dx.doi.org/10.1590/1676-06032015010714

\begin{abstract}
The relative condition factors (Kn) of the fishes Astyanax paranae, Phalloceros harpagos and Poecilia reticulata were used as a means of assessing the influence of environmental conditions on the well-being of sub - populations of these species, with the eventual aim of using them as bioindicators of disturbance in tributary streams of the Monjolinho River, in São Carlos - SP. The power-law curve generated by the length-weight relationship indicated a positive allometric growth for the three species studied. Overall, the canonical correspondence analysis (CCA) positively correlated average Kn of $A$. paranae with well oxygenated and oligotrophic environments, typical of conserved areas or near the natural state. For the average value of $\mathrm{Kn}$ obtained for Phalloceros harpagos species, there was no significant difference between natural and disturbed areas. However, the CCA positively correlated the mean $\mathrm{Kn}$ of the species $P$. reticulata from similar environments with higher trophic level, suggesting that this species is indicative of disturbance.
\end{abstract}

Keywords: Biomonitoring, condition factor, length-weight relationship, degradation, bioindicators.

BARRILLI, G.H.C, ROCHA, O., NEGREIROS, N.F., VERANI, J.R. Influência da integridade ambiental dos afluentes do Rio Monjolinho sobre o fator de condição relativo (Kn) da ictiofauna local. Biota Neotropica. 15(1): e20140107. http://dx.doi.org/10.1590/1676-06032015010714

Resumo: Os fatores de condição relativo $(\mathrm{Kn})$ de Astyanax paranae, Phalloceros harpagos e Poecilia reticulata foram utilizados como ferramenta para avaliar a influência da qualidade ambiental sobre o bem estar de sub-populações destas espécies, visando utilizá-las como bioindicadoras de distúrbios em córregos afluentes do rio Monjolinho, no município de São Carlos - SP. A curva potencial gerada pela relação peso-comprimento indicou um crescimento do tipo alométrico positivo para as três espécies estudadas. No geral, a análise de correspondência canônica (CCA) correlacionou positivamente o Kn médio da espécie $A$. paranae com ambientes bem oxigenados e oligotróficos, característicos de áreas preservadas ou próximas do estado natural. Para o valor médio do Kn obtido para a espécie Phalloceros harpagos, não ocorreram diferenças significativas entre áreas naturais e perturbadas. Entretanto, a CCA correlacionou positivamente o Kn médio da espécie Poecilia reticulata a ambientes impactados, com maior grau de trofia, o que sugere que o fator de condição relativo desta espécie pode ser utilizado como indicador de distúrbios, neste caso, ocasionado pela poluição orgânica.

Palavras-chave: Biomonitoramento, Fator de condição, relação peso-comprimento, degradação, bioindicadores.

\section{Introduction}

Natural ecosystems have suffered heavily over the last years from the impact of the combined effects of urbanization and other anthropogenic activities resulting from population growth. Many aquatic environments, such as rivers, lakes and reservoirs, which provide essential services to humanity, have undergone a number of changes due to human interference (König et al., 2008). In this context, aquatic communities are constantly exposed to pollution by the large number of compounds released into water bodies from various emission sources, including industrial effluent discharge, domestic sewage, agricultural waste and others (Rashed, 2001). Thereby, the environmental quality or degradation level of 
these ecosystems may be reflected by their biological communities, which respond differently to the effects of the disturbing agents, providing an indicator to assess the effects of these disorders (Barbour et al., 1999).

The organisms most fequently used in the assessment of the impacts on aquatic ecosystems are the benthic macroinvertebrates, fish and periphyton (Goulart \& Callisto, 2003). In ichthyofauna studies, for instance, the parameters usually analyzed in the study of populations are the size and weight of the organisms. The length-weight relationship of fish is an important tool to distinguish aspects of their biology, physiology and ecology, and combined with other quantitative features, such as growth, recruitment and mortality, it provides valuable information about the species structure in an environment (Lizama \& Ambrósio, 1999).

Using the relationship between body weight and length, it is possible to derive a parameter that is a measure of wellness, providing information about how the animal takes advantage of the available resources. This parameter, known as the relative condition factor $(\mathrm{Kn})$, is an important and powerful tool to demonstrate changes in the condition of fish over a certain period of time and can be used to indicate nutritional status, environmental changes, the reproductive period, the dietary changes period, the fat accumulation (Le Cren, 1951; Gomiero \& Braga, 2003) and parasite infections (Lemos et al., 2007), making it possible to compare populations that are subjected to different climate conditions, water temperature, salinity and density, food availability and other conditions (Lizama \& Ambrósio, 2002; Rocha et al., 2005; Rêgo et al., 2008). Under normal conditions, the theoretically expected value of $\mathrm{Kn}$ is 1 , whereas any event that interferes with the health or welfare of the fish can produce variations in this value.

The improper use of land and natural resources, resulting from urban development without proper planning and agricultural activities in the catchment area of the Monjolinho River have caused large disturbances in the basin, especially in the area of headwaters in the city of São Carlos during the last few decades (Sé, 1992). The accelerated development occurring in areas where these headwaters are located interferes directly with the stability of aquatic ecosystems and, therefore, affects the water quality and aquatic biota across the whole river basin.

The aim of this study was to assess the conditions in the tributary streams of the upper portion of the Monjolinho River system, through chemical, physical and biological analysis, as well as to test the relative condition factor as an indicator of environmental influence on the physiological state of the fish species present in these streams, with a view to using them as indicators of disturbance.

\section{Material and Methods}

The Monjolinho River basin covers an area of approximately $275 \mathrm{~km}^{2}$, at an elevation between 700 and 800 meters above sea level. The greater part of this basin is located in the district of São Carlos city, in the state of São Paulo. The city is located in an area of accelerating urban development and, therefore, of considerable anthropogenic impact. The length of the river is $43.25 \mathrm{~km}$ (Sé, 1992).

The stretches used as sampling sites were chosen to include a variety of environmental and anthropogenic influences (natural, rural and urban areas) in several tributaries belonging to the upper portion of the Monjolinho River catchment area. The study area is mapped in Figure 1, with stream names and sampling sites.

A brief description of each site follows:

- Espraiado $1\left(21^{\circ} 58^{\prime} 17.5^{\prime \prime} \mathrm{S} ; 47^{\circ} 52^{\prime} 18^{\prime \prime} \mathrm{W}\right)$ : Stream stretch in an area of dense and structured native vegetation, closed canopy, legally defined as a preserved area; a reference site for this study.

- Espraiado 2 ( $\left.21^{\circ} 58^{\prime} 52^{\prime \prime} \mathrm{S} ; 47^{\circ} 52^{\prime} 26^{\prime \prime} \mathrm{W}\right)$. Stream stretch in an area with preserved riparian vegetation near a canalized portion. Both stretches (Espraiado 1 and 2) are located on Federal University of São Carlos land, enclosed in an area covered by cerrado sensu stricto and replanted Eucalyptus sp. forest.

- Belvedere $\left(21^{\circ} 59^{\prime} 54.3^{\prime \prime} \mathrm{S} ; 47^{\circ} 52^{\prime} 13.9^{\prime \prime} \mathrm{W}\right)$ : stretch located in an area with a small fragment of riparian vegetation, but with signs of burning and household waste, as well as earthworks that indicate the expansion of the Belvedere Park neighborhood. The stream is located in an urban development.

- Ponte de Tábua 1 ( $\left.22^{\circ} 00^{\prime} 32.1^{\prime \prime} \mathrm{S} ; 47^{\circ} 51^{\prime} 38.8^{\prime \prime} \mathrm{W}\right)$ : stretch located in an urban area, near the Sabara Park condominium, with fragments of riparian vegetation and domestic waste collected along the stretch.

- Ponte de Tábua 2 ( $\left.21^{\circ} 59^{\prime} 35.1^{\prime \prime} \mathrm{S} ; 47^{\circ} 51^{\prime} 43.2^{\prime \prime} \mathrm{W}\right)$ : stretch located in an urban area; Jardim Veneza and Jardim Munique neighborhoods close to it, without riparian vegetation, with pipe for sewage discharge and grazing animals nearby.

- Canchim stream (21 $\left.59^{\prime} 21.4^{\prime \prime} \mathrm{S} ; 47^{\circ} 51^{\prime} 14.2^{\prime \prime} \mathrm{W}\right)$ : stretch located inside Coqueiros Farm, with riparian vegetation and without evidence of household wastes.

- São Rafael $\left(22^{\circ} 00^{\prime} 52^{\prime \prime} \mathrm{S} ; 47^{\circ} 51^{\prime} 9.4^{\prime \prime} \mathrm{W}\right)$ : stretch located close to Jardim Tangará and São Rafael residential neighborhoods and with evidence of disturbance.

- Douradinho $\left(22^{\circ} 00^{\prime} 37^{\prime \prime} \mathrm{S} ; 47^{\circ} 50^{\prime} 28.3^{\prime \prime} \mathrm{W}\right)$ : stretch located inside Santa Joana Farm, characterized by a large forest fragment.

To analyze the sampling stretches, we used the Habitat Diversity Rapid Assessment Protocol described by Callisto et al. (2002), which assesses a set of variables and indicates the degree of conservation of the habitat as: natural (up 60 points), altered (41-60 points) or impacted (0-40 points).

Sampling was conducted in the months of July and August 2013: a metal wire sieve mesh (diameter $=0.75 \mathrm{~m}$, mesh $=3$ $\mathrm{mm})$ and a net $(0.50 \mathrm{~m}$ in diameter) were used to catch the fish fauna, with a sampling effort of one hour in each stretch (approximately 50 meters long). The specimens were fixed in $10 \%$ formalin and preserved in $70 \%$ alcohol for later identification and biometrics analysis. For taxonomic identification, the specialized bibliography, keys and descriptions available in the literature were used (Britski, 1972 Britski et al., 1999, modified by Casatti et al., 2001; Castro et al., 2004; Oliveira, 2006; Grace \& Pavanelli, 2007; Lucinda, 2008), as well as the help of ichthyologists. Species with greater occurrence constancy were selected, according to the criteria of Dajoz (1983), as well as those with higher relative abundance at the collection sites, and the species that were present in the habitats of lowest and highest degradation were taken as references.

For each selected taxon, measurements of standard length (Ls) and fresh weight (Wo) were taken with digital calipers (King Tools) and a precision balance (Marte AS 2000c). These 


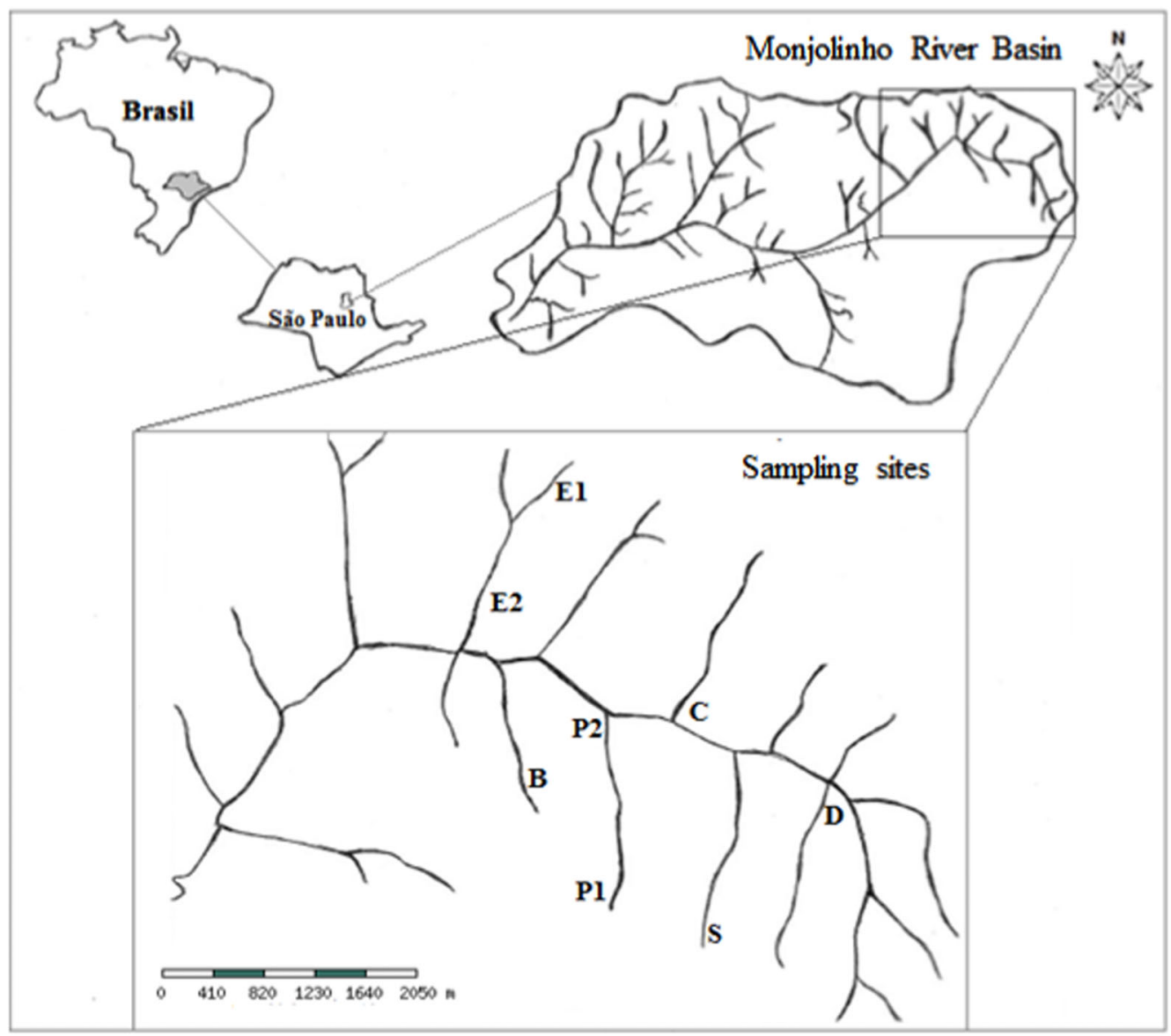

Figure 1. Map showing location of the Monjolinho River basin, São Carlos - SP, with tributary streams indicated. Espraiado (E1 and E2), Belvedere (B), Ponte de Tábua (P1 and P2), Canchim (C), São Rafael (S) and Douradinho.

data were used to fit an overall weight-length curve for each species, by adjusting $\mathrm{a}$ and $\mathrm{b}$, the equation $\mathrm{W}=\mathrm{a} \cdot \mathrm{Ls}^{\mathrm{b}}$ (Le Cren, 1951). With the estimated values of coefficients " $a$ " and " $b$ ", the theoretical expected weights (We) for the respective values of standard length (Ls) were calculated. The values of the relative condition factor $(\mathrm{Kn})$ calculated by the equation $\mathrm{Kn}=\mathrm{Wo} / \mathrm{We}$ for individuals sampled in each environment, and the $\mathrm{Kn}$ data sets for each species and their habitats were compared by the nonparametric Kruskal-Wallis test (complemented by Dunn's test) at a significance level of 5\%. Finally, each mean Kn was compared with the hypothetical average $(\mathrm{Kn}=1)$ by student's $t$-test (Zar, 2010).

The physical and chemical data: $\mathrm{pH}$, electrical conductivity, dissolved oxygen concentration and water temperature, were measured "in situ" with a HORIBA U-10 multiprobe, alongside the water sampling. The inorganic nutrients analyzed were: total phosphorus and nitrogen (Valderrama, 1981), nitrite (Bendchreider \& Robinson, 1952, cited by Golterman et al., 1978), nitrate (Mackereth et al. 1978), ammonium (Koroleff 1976, cited by Mackereth et al. 1978) and dissolved total phosphate, organic phosphate and inorganic phosphate (Strickland \& Parsons, 1960). Once the nutrient concentrations were established, the trophic state index (TSI) of Carlson (1977) modified by Lamparelli (2004) was calculated, using the total phosphorus concentration.

Canonical correspondence analysis (CCA), followed by a Monte Carlo test, with 999 random permutations, was used to test the existence of significant associations between environmental variables and the relative condition factor of each species, using the program CANOCO 3:12 (Šmilauer \& Ter Braak, 2002).

\section{Results}

Fishes belonging to eight species, totaling 616 specimens, were collected in the sampled streams, of which Astyanax paranae (Eigenmann, 1914), Phalloceros harpagos (Lucinda, 2008) and Poecilia reticulata (Peters, 1859) were more numerous, both in occurrence $(\mathrm{O})$ and relative abundance (A), than others: Hypostomus ancistroides (Ihering, 1911), Geophagus brasiliensis (Quoy \& Gaimard, 1824), Rhamdia quelen (Quoy \& Gaimard, 1824), Gymnotus carapo (Linnaeus, 1758) and Hyphessobrycon anisitsi (Eigenmann, 1907) Table 1. Therefore, the first three were selected for the length-weight relationship and relative condition factor.

The score obtained for the Rapid Assessment Protocol, trophic state index (TSI) and physical and chemical variables are presented in table 2 . The highest values for the physical and chemical variables, with the exception of dissolved oxygen, $\mathrm{pH}$ and temperature, were recorded in Belvedere stream. The lowest dissolved oxygen concentration was found in this stream too.

The Habitat Diversity Rapid Assessment Protocol classified as natural habitats $(\mathrm{N})$ the Espraiado stream (E1 and E2), as altered streams (A) the Douradinho (D), Canchim (C), Ponte 
Table 1. Composition, occurrence $(\mathrm{O})$ and relative abundance $(\mathrm{A})$ of the species collected in tributary streams of the Monjolinho River in the district of São Carlos - SP. Streams: Espraiado (E1 and E2), Douradinho (D), Canchim (C), Belvedere (B), Ponte de Tábua (P) and São Rafael (S).

\begin{tabular}{|c|c|c|c|c|c|c|c|c|c|c|}
\hline \multirow[b]{2}{*}{ Species } & \multicolumn{9}{|c|}{ Streams } & \multirow[b]{2}{*}{ A $(\%)$} \\
\hline & E1 & $\mathbf{E 2}$ & $\mathbf{D}$ & $\mathbf{C}$ & B & P1 & $\mathbf{P 2}$ & $\mathbf{S}$ & O $(\%)$ & \\
\hline Astyanax paranae & 34 & 34 & 53 & 10 & - & 31 & 19 & - & 75 & 29.4 \\
\hline Poecilia reticulata & - & - & - & - & 47 & 62 & 32 & - & 37.5 & 22.9 \\
\hline Phalloceros harpagos & - & 52 & 40 & 15 & - & 61 & 19 & 34 & 75 & 36.0 \\
\hline Hypostomus ancistroides & - & - & - & 1 & - & 13 & 21 & - & 37.5 & 5.7 \\
\hline Geophagus brasiliensis & - & - & 3 & - & - & - & 5 & - & 25 & 1.3 \\
\hline Rhamdia quelen & - & - & - & - & - & - & 4 & - & 12,5 & 0.6 \\
\hline Gymnotus carapo & - & - & - & - & - & 1 & 5 & - & 25 & 1.0 \\
\hline Hyphessobrycon anisitsi & - & - & - & 10 & - & - & 10 & - & & 3.2 \\
\hline
\end{tabular}

de Tábua (P1 and P2) and São Rafael (S), and as impacted stream (I) the Belvedere (B). The value of TSI characterized the Espraiado stream (E1 and E2) as oligotrophic (O), the Douradinho, Canchim, Ponte de Tábua (P1 and P2) and São Rafael streams as mesotrophic (M), and Belvedere stream as eutrophic (E) (Table 2).

The equations obtained for the length-weight relationship for Astyanax paranae, Phalloceros harpagos and Poecilia reticulata in the streams under study were, respectively, $\mathrm{W}=$ $0.00001399 \mathrm{Ls}^{3.180}, \mathrm{~W}=0.000003791 \mathrm{Ls}^{3.558}$ and $\mathrm{W}=$ $0.000007636 \mathrm{Ls}^{3.4142}$. The values of the exponents of LS $(b>3)$ characterize the growth of the species as positive allometric; therefore, there is a greater than expected increase in weight as the standard length grows (Figure 2).

The data shown in Figure 3 indicate that Astyanax paranae showed significantly lower values of the mean the relative condition factor $(\mathrm{Kn})$ in the Ponte de Tábua stream (PT1 and PT2) than in other streams where the species occurred; both in PT1 and PT2, Kn was smaller than 1 (0.94 and 0.95, respectively). The $\mathrm{Kn}$ values for the species in Canchim $(\mathrm{Kn}=$ $1.05)$ and Douradinho streams $(\mathrm{Kn}=1.03)$ were significantly higher than 1, suggesting significantly more suitable environmental conditions for this fish than those in sites PT1 and PT2.

In contrast, Phalloceros harpagos individuals collected in Douradinho stream were in poor body condition, shown by the low average value of $\mathrm{Kn}(\mathrm{p}<0.05)$ relative to the other streams and the standard $\mathrm{Kn}(\mathrm{Kn}=1)$.

The specimens of Poecilia reticulata showed a higher Kn value in Belvedere stream than in all the other streams where this species was recorded. Besides being the highest value among all the streams, the average $\mathrm{Kn}$ of this species in this stream was significantly higher thant the standard value $(\mathrm{Kn}=1)$ (Figure 3).

In the canonical correspondence analysis (CCA), the first two axes explained $98.5 \%$ of the total variability of the data (Figure 4). In general terms, the Belvedere stream (Bvd) was associated with higher nutrient concentrations, environmental disturbance, lower dissolved oxygen and higher abundance of Poecilia reticulata individuals. The species Astyanax paranae was correlated with natural habitat streams, with low nutrient concentrations and higher dissolved oxygen concentrations. In turn, Phalloceros harpagos individuals were associated with altered conditions, as in:

Table 2. Values related to chemical, physical, habitat diversity rapid assessment protocol and trophic state index (TSI) in tributary streams of Monjolinho River, in district of São Carlos - SP. Streams: Espraiado (E1 and E2), Douradinho (D), Canchim (C), Belvedere (B), Ponte de Tábua (P) and São Rafael (S). O - Oligotrophic, M - Mesotrophic, E - Eutrophic, N - Natural, A - Altered and I - Impacted.

\begin{tabular}{|c|c|c|c|c|c|c|c|c|}
\hline Variables & E1 & E2 & D & $\mathbf{C}$ & B & P1 & $\mathbf{P 2}$ & $\mathbf{S}$ \\
\hline Nitrite $\left(\mu \mathrm{g} . \mathrm{L}^{-1}\right)$ & 1.4 & 1.4 & 1.9 & 1.4 & 92.6 & 2.7 & 2.1 & 3.1 \\
\hline Nitrate $\left(\mu \mathrm{g} . \mathrm{L}^{-1}\right)$ & 11.9 & 39.3 & 249.7 & 18.8 & 961.4 & 337.1 & 163.3 & 961.4 \\
\hline Ammonium $\left(\mu \mathrm{g} . \mathrm{L}^{-1}\right)$ & 30.4 & 35.6 & 64.1 & 43.1 & 692.9 & 105.3 & 81.9 & 60.2 \\
\hline DIN (mg.L $\left.{ }^{-1}\right)^{*}$ & 0.04 & 0.08 & 0.32 & 0.06 & 1.75 & 0.45 & 0.25 & 1.02 \\
\hline Total N $\left(\mu \mathrm{g} . \mathrm{L}^{-1}\right)$ & 206.2 & 221.2 & 414.5 & 134.7 & 1919.4 & 604.4 & 326.5 & 810.5 \\
\hline Inorganic phosphate $\left(\mu \mathrm{g} . \mathrm{L}^{-1}\right)$ & 13.3 & 12.2 & 11.2 & 15.3 & 98.3 & 11.8 & 16.5 & 11.5 \\
\hline Total dissolved $\mathbf{P}\left(\mu \mathrm{g} . \mathrm{L}^{-1}\right)$ & 18.1 & 17.0 & 15.5 & 21.7 & 119.1 & 14.6 & 21.3 & 15.2 \\
\hline Organic $\mathbf{P}\left(\mu \mathrm{g} . \mathrm{L}^{-1}\right)$ & 4.7 & 4.8 & 4.3 & 6.3 & 20.9 & 2.8 & 4.9 & 3.7 \\
\hline Total $\mathbf{P}\left(\mu \mathrm{g} . \mathrm{L}^{-1}\right)$ & 19.7 & 20.2 & 47.7 & 36.6 & 164.8 & 42.8 & 41.5 & 53.6 \\
\hline pH & 6.5 & 6.5 & 7.4 & 6.9 & 6.9 & 6.9 & 5.4 & 6.7 \\
\hline Dissolved Oxygen (mg. $\left.\mathrm{L}^{-1}\right)$ & 8.1 & 10.7 & 8.4 & 5.7 & 4.0 & 5.4 & 6.5 & 5.8 \\
\hline Conductivity $\left(\mu \mathrm{S} . \mathrm{cm}^{-1}\right)$ & 9.7 & 5.0 & 39.0 & 19.0 & 107.0 & 42.3 & 31.3 & 107.0 \\
\hline Temperature $\left({ }^{\circ} \mathrm{C}\right)$ & 17.5 & 16.5 & 17.8 & 20.3 & 19.4 & 18.3 & 18.2 & 21.7 \\
\hline TSI & 49.4 & 49.6 & 54.0 & 52.6 & 60.5 & 53.5 & 53.3 & 54.6 \\
\hline Classification (TSI) & $\mathrm{O}$ & $\mathrm{O}$ & $\mathrm{M}$ & $\mathrm{M}$ & $\mathrm{E}$ & $\mathrm{M}$ & $\mathrm{M}$ & $\mathrm{M}$ \\
\hline Assessment Protocol & 83.0 & 80.0 & 58.0 & 59.0 & 38.0 & 45.0 & 46.0 & 42.0 \\
\hline Classification & $\mathrm{N}$ & $\mathrm{N}$ & A & $\mathrm{A}$ & I & A & A & A \\
\hline
\end{tabular}

*DIN - Dissolved inorganic Nitrogen 

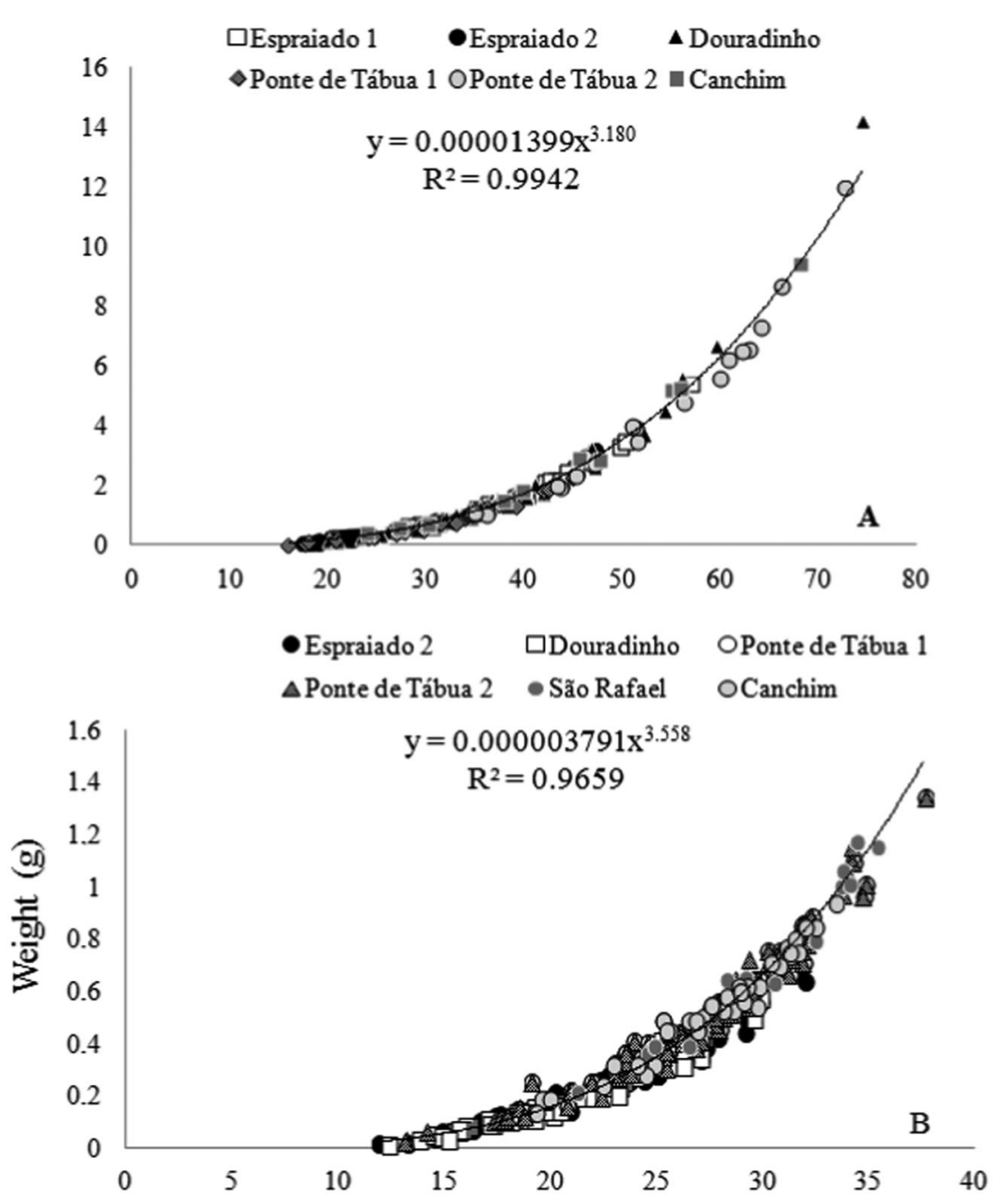

- Belvedere OPonte de Tábua $1 \Delta$ Ponte de Tábua 2

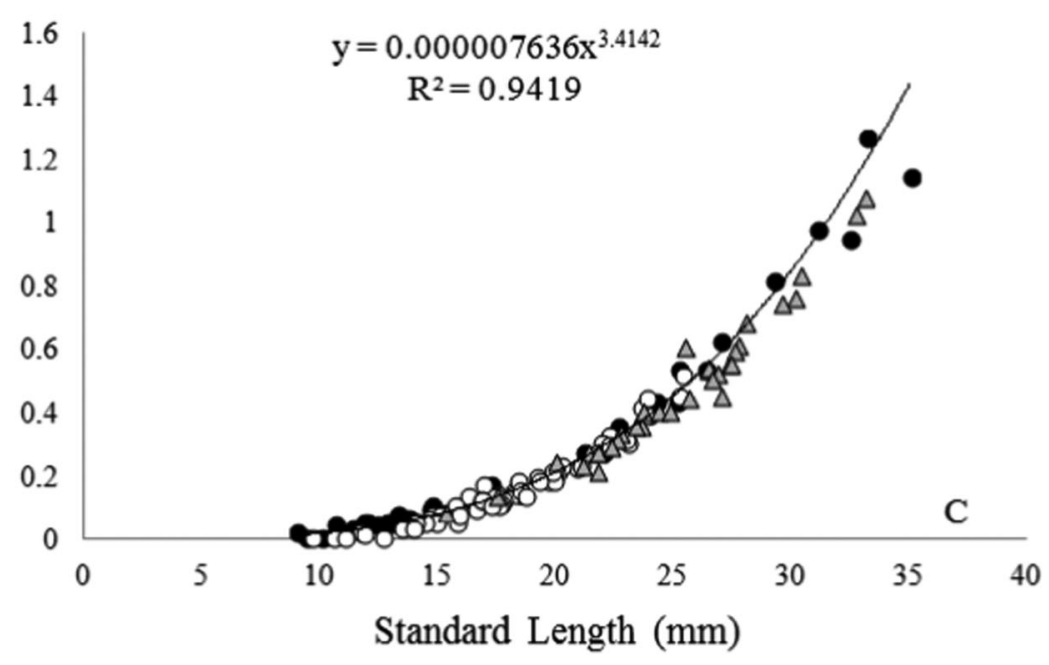

Figure 2. Length-weight relationship of the fish (A) Astyanax paranae, (B) Phalloceros harpagos and (C) Poecilia reticulata in the tributary streams of the upper Monjolinho river streams in São Carlos - SP.

Canchim (Cch), Ponte de Tábua (PT1 and PT2) and São Rafael (SR), but not Douradinho stream. The Monte Carlo test showed that the differences in dissolved oxygen, nitrite and total phosphorus concentrations were significant $(\mathrm{p}<0.05)$.

\section{Discussion}

The physical and chemical analysis, the Habitat Rapid Assessment Protocol of habitats and the trophic state index indicated a range of sites, from very clean to very impacted. 
Barrilli, G.H.C. et al.

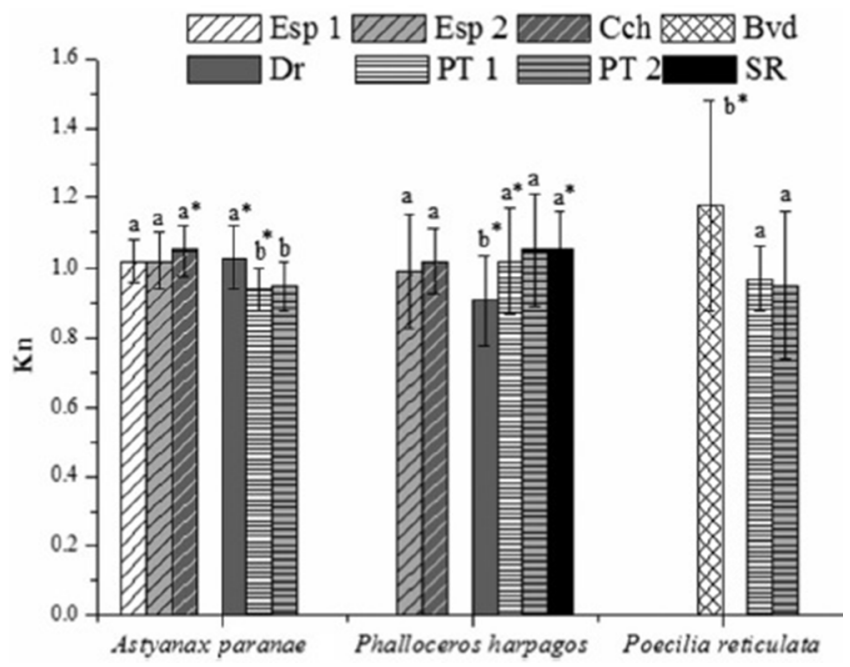

Figure 3. Relative Condition Factor (Kn) of each species in selected tributaries of Monjolinho River (São Carlos - SP) during the dry season: Espraiado (Esp1 and Esp2), Canchim (Cch), Belvedere (Bvd), Douradinho (Dr), Ponte de Tábua (PT1 and PT2) and São Rafael (SR). Different letters represent statistically significant differences between individuals of the same species caught in distinct streams (KruskalWallis test, $\mathrm{p} \leq 0.05$, followed by the Dunn multiple comparison test). Same letters correspond to the absence of statistical significance (Kruskal-Wallis, $\mathrm{p}>0.05$ ). ${ }^{*}$ Statistically different from 1 (Student $t$ test, $\mathrm{p} \leq 0.05)$ in the stream indicated.
Being located in conservation areas, with well structured vegetation and far from pollutant emission sources, Espraiado stream, 1 and 2, have a good environmental quality, with nutrient concentrations below the regional limits for natural systems, according to those described by Tundisi \& Matsumura-Tundisi (2008). The Habitat Rapid Assessment Protocol and trophic state index corroborated the improved environmental quality of these stretches, classifying them as natural and oligotrophic environments, respectively. However, these instruments characterized the Canchim, Douradinho, Ponte de Tábua1 and 2 and São Rafael streams as mesotrophic and altered. In all streams except for Espraiado and Canchim streams, the dissolved inorganic nitrogen concentrations (ammonium, nitrite and nitrate) were higher than those found in natural habitats with low human intervention (around 0.12 mg. $\left.\mathrm{L}^{-1}\right)$, according to Allan \& Castillo (2007).

In Belvedere stream, high nutrient concentrations and electrical conductivity were recorded compared to the other streams. The trophic state index and the Habitat Rapid Assessment Protocol characterized the Belvedere stream as eutrophic and impacted, respectively. Furthermore, evidence of fires was found in the riparian vegetation. These results corroborate those of Souza (2011), who reported, at the same site, a stream that proved to be negatively impacted.

The values of exponent $b$ values for the species studied were within the limits indicated by Vazzoler (1996), ranging from 2.4 to 4.0 for most fish species. According to Verani (1980),

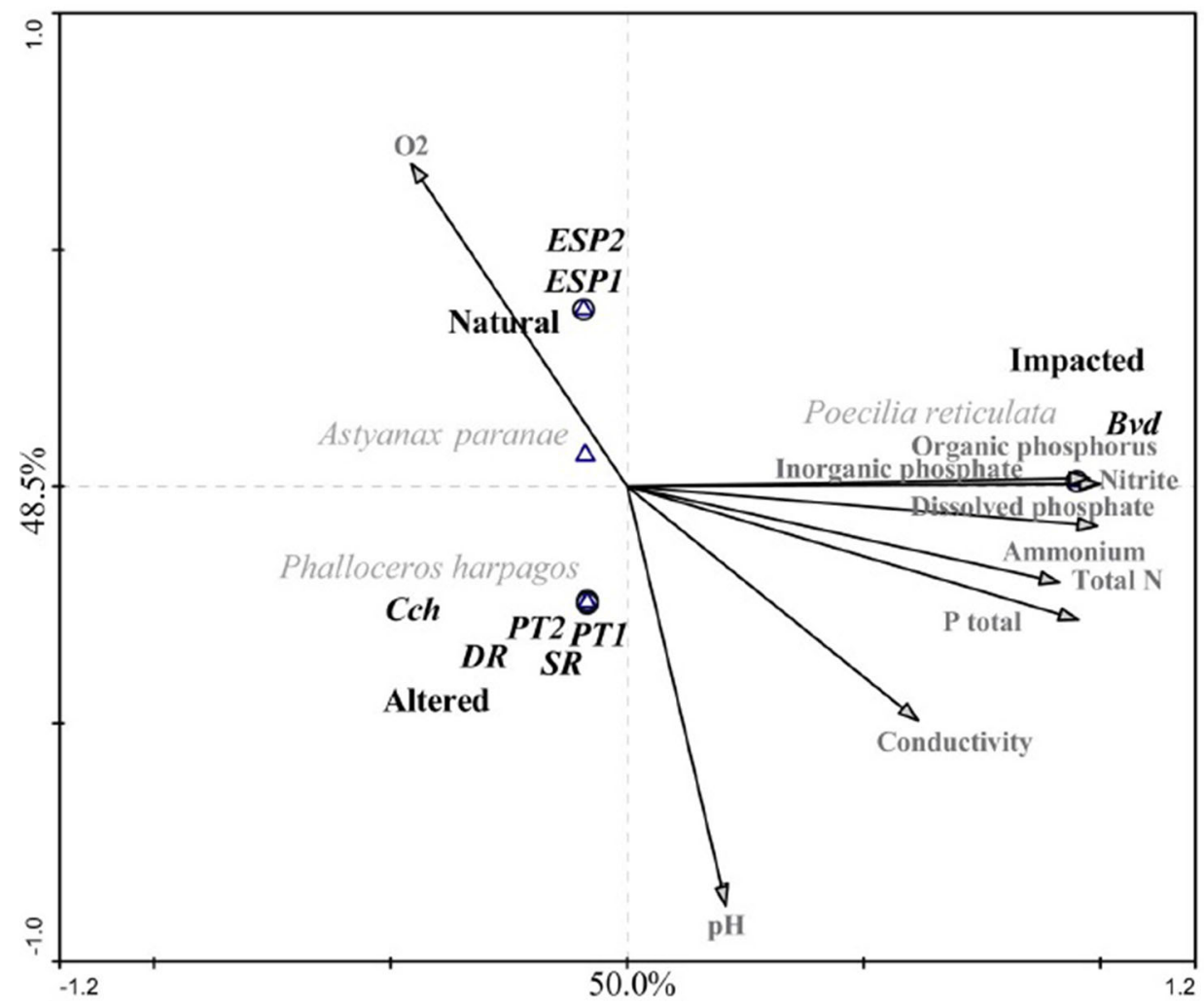

Figure 4. Canonical correspondence analysis (CCA) relating the environmental variables, the relative condition factor of the species Astyanax paranae, Phalloceros harpagos and Poecilia reticulata and scores in rapid assessment of habitats of tributaries of Monjolinho river (São Carlos - SP), during dry season. Streams: Espraiado (Esp1 and Esp2), Canchim (Cch), Belvedere (Bvd), Douradinho (Dr), Ponte de Tábua (PT1 and PT2) and São Rafael (SR). 
variations in this allometric coefficient can be related to environmental conditions and inherent biogenetic features of each species. Thus, the fact that this exponent exceeded 3 indicates that all three species, Astyanax paranae, Phalloceros harpagos and Poecilia reticulata at the study sites, showed a greater weight gain than predicted during growth, featuring positive allometric growth (Wooton, 1991).

In the CCA the relative condition factor $(\mathrm{Kn})$ showed that Astyanax paranae was in good condition in the well-oxygenated and less nutrient environments in Espraiado stream, as noted in stretches 1 and 2. However, there were no significant differences in the $\mathrm{Kn}$ values between the stretches classified as natural and oligotrophic and those classified as altered and mesotrophic, except for the Ponte de Tábua stream, stretches 1 and 2, where below average values of $\mathrm{Kn}$ were found for this species.

The results found by Lima-Junior (2004) and Orsi (2004) for the species Astyanax altiparanae demonstrated a fall in the condition factor at most degraded sites. In contrast, JuniorMartins \& Schulz (2001) and Albert et al. (2005) found an increase in $\mathrm{Kn}$ for another species of lambari, Astyanax fasciatus, in polluted sites. One possible explanation for the higher values of $\mathrm{Kn}$ for Astyanax paranae found in the subpopulations in Canchim and Douradinho streams, classified as mesotrophic and altered in this study could be that, within certain limits, eutrophication can increase the productivity of an ecosystem (Toledo et al., 1983), in the short term, be beneficial to the species. However, an excessive level of productivity can be harmful because it adversely alters the water quality, causes profound changes in the biogeochemical cycles of aquatic ecosystems and also leads to changes in community structure, destroying the natural balance of the food web (Toledo et al.,1983).

The low Kn values found for the subpopulation in the Ponte de Tábua stream (stretch 1 and 2) may be related to exposure of Astyanax paranae to the high nitrite concentrations recorded when compared to those reported in other streams where this species occurred. According to Baldisseroto (2002), nitrite can be toxic to fish, even at low concentrations, because it combines with the blood's hemoglobin, hindering the transport of oxygen and resulting in tissue hypoxia (Jensen \& Knudsen, 1997). Even at non-lethal levels, it can cause a weakening of the immune system of some species, leading to reduced growth and lower weight gain (Hanson \& Grizzle, 1985).

For Phalloceros harpagos, the canonical correspondence analysis (CCA) related the species to environments with moderate levels of pollution, which suggests that it is tolerant to environments with moderate disturbance. The relative condition factor did not differ statistically between environments of different degrees of disturbances except for the subpopulation from Douradinho stream. A similar result was obtained by Araújo et al. (2009) for the population of Phalloceros caudimaculatus in the Paraiba do Sul River. The low condition factor obtained for the subpopulation of $P$. harpagos in Douradinho stream was possibly a result of competition with $A$. paranae, which occurs in the same stream and in greater numerical density, and the fact that these species have similar trophic niches and a degree of flexibility that allows them to occupy a range of environments, from moderately impacted areas to nearly natural ones (Orsi, 2004). Thus, according to this author, the fish of this genus (Astyanax spp.) can use available resources efficiently and can also compete well in moderately disturbed habitats, which can be seen from the higher Kn value of this species in Douradinho stream compared, to Phalloceros harpagos.

Poecilia reticulata was highly correlated with negatively impacted environments, characterized by higher contents of nutrients and low oxygenation of the water. This has already been observed for this species by Lemes \& Garutti (2002), Dyer (2003) and Cunico et al. (2006) who reported a high density of this species in impacted streams. According to Oliveira \& Bennemann (2005), Poecilia reticulata is an exotic species that shows resilience in environments disturbed by human activity, owing to its opportunistic habits and diversified diets. In the present study, the relative condition factor of $P$. reticulata was highest in Belvedere stream, where the most severe conditions of eutrophication were observed, confirming that this species is not affected by poor environmental quality. In general, the species of the order Cyprinodontiformes are more tolerant of environmental degradation and can remain in such sites long after all the other fish disappear (Araújo, 1998; Chapman \& Chapman, 1992). According to the authors cited here, the flexibility in the diet and the ability to survive and reproduce in waters with low oxygen facilitate the exploration of the habitat by this fish.

In the streams of the Monjolinho river basin, the varying degrees of environmental quality influenced differently the relative condition factor of the species. Astyanax paranae was more sensitive to environments with higher nutrient and oxygen concentrations, while Phalloceros harpagos seems to be tolerant, since its condition factor did not differ between environments, with the exception of Douradinho stream, where the $\mathrm{Kn}$ value probably reflected the competition for food with A. paranae. On the other hand, $P$. reticulata had the highest $\mathrm{Kn}$ value in the environment with lowest oxygen and highest nutrient concentrations, suggesting that this species is resistant to disturbed environments. The relative condition factor of fishes, combined with the analysis of environmental conditions, can be a useful tool for studies assessing the environmental quality of streams.

\section{Acknowledgments}

We thank CAPES (Coordination for the Improvement of Higher Education Personnel) for the grant to the first author, the technicians, José Valdecir de Lucca e Alcídio Culósio Filho, for their assistance in sampling, and ichthyologists Dr. Alexandre Kannebley de Oliveira and Dr. Evelise Nunes Fragoso de Moura for their contributions.

\section{References}

ALBERTO, A., CAMARGO, F.M., VERANI, J.R \& COSTA, O.F.T. 2005. Health variables and gill morphology in the tropical fish Astyanax fasciatus from a sewage-contaminated river. Ecotoxicology and Environmental Safety 6: p. 247-255.

ALLAN, J.D. \& CASTILLO, M.M. 2007. Stream Ecology Structure and Function of Running Waters. Springer, 2nd. Dordrecht, The Netherlands, 436p.

ARAÚJO, F.G. 1998. Adaptação do índice de integridade biótica usando a comunidade de peixes para o rio Paraíba do Sul. Revista Brasileira de Biologia v.58, n.4, p. 547-558.

ARAÚJO, F.G., PEIXOTO, M.G., PINTO, B.C.T. \& TEIXEIRA, T.P. 2009. Distribution of guppies Poecilia reticulata (Peters, 1860) and Phalloceros caudimaculatus (Hensel, 1868) along a polluted stretch of the Paraíba do Sul River, Brazil. Brazilian Journal of Biology. [online]. 2009, vol.69, n.1, pp. 41-48 ISSN 1519-6984. 
BALDISSEROTTO, B. 2002 Fisiologia de peixes aplicada à piscicultura. Santa Maria: UFSM. 212p.

BARBOUR，M.T., GERRITSEN，J., SNYDER，B.D. \& STRIBLING, J.B. 1999. Rapid Bioassessment Protocols for Use in Streams and Wadeable Rivers: Periphyton, Benthic Macroinvertebrates and Fish, 2a ed. EPA 841-B-99-002. U.S. Environmental Protection Agency; Office of Water; Washington, D.C.

BRITSKI, H.A. 1972. Peixes de água doce do Estado de São Paulo: sistemática. In: Comissão Interestadual da Bacia Paraná-Uruguay. Poluição e piscicultura: notas sobre ictiologia, poluição e piscicultura. São Paulo: Faculdade de Saúde Pública da USP; Instituto de Pesca. p. 79-108.

CAllisto, M., FERREIRA, W., MORENO, P., GOUlART, M., PETRUCIO, M. 2002. Aplicação de um Protocolo de Avaliação Rápida da Diversidade de Habitats em Atividades de Ensino e Pesquisa (MG-RJ). Acta Limnologica Brasiliensia, v. 14, p. 91-98.

CASATTI, L., LANGEANI, F. \& CASTRO, R.M.C. 2001. Peixes de riacho do Parque Estadual Morro do Diabo, bacia do alto rio Paraná, SP. Biota Neotropica 1(1). Disponível em: http://www.biotaneotropica. org.br/v1n12/pt/abstract?inventory+BN00201122001: Acesso em 04/ Jan/2013).

CASTRO, R.M.C., CASTRO, R.M.C., CASATTI, L., SANTOS, H.F., FERREIRA, K.M., RIBEIRO, A.C., BENINE, R.C., DARDIS, G.Z.P., MELO, A.L.A., STOPIGLIA, R., ABREU, T.X., BOCKMANN, F.A., CARVALHO, M., GIBRAN, F.Z.G. \& LIMA, F.C.T. 2004. Estrutura e composição da ictiofauna de riachos da bacia do Rio Grande no estado de São Paulo, sudeste do Brasil. Biota Neotrop., Campinas, v. 4, n. 1, 2. Disponível em: $<$ http://www.scielo.br/scielo.php?script=sci_arttext\&pid=S1676$06032004000100006 \& \operatorname{lng}=$ en\&nrm=iso $>$. Accesso em: 14 Jan. 2014.

CHAPMAN, L.J. \& CHAPMAN, C.A. 1992. Variation in the structure of Poecilia gillii populations. Copeia, p. 908-913.

CUNiCO, A.M., AGOSTINHO, A.A., \& LATINI, J.D. 2006. Influência da urbanização sobre as assembléias de peixes em três córregos de Maringá, Paraná. Revista Brasileira de Zoologia 23(4): $1101-1110$

DAJOZ, R. 1983. Ecologia Geral. 4 ed. Vozes, São Paulo.

DYER, S.D., PENG, C., MCAVOY, D.C, FENDINGER, N.J., MASSCHELEYN, P., CASTILHO, L.V. \& LIM, J.M. 2003.The influence of untreated wastewater to aquatic communities in the Balatuin River, the Philippines. Chemosphere, Kidlington, 52: 4353.

GOLTERMAN, H.L, CLYM, R.S. \& OHNSTAD, M.A.M. 1978. Methods for Physical and Chemical Analysis of Fresh Waters. 2nd. ed. Oxford: Blackwell Scientific Publications, 215 p.

GOMIERO, L.M. \& BRAGA, F.M.S. 2003. Relação peso-comprimento e fator de condição para Cichla cf. ocellaris e Cichla monoculus (Perciformes, Cichlidae) no reservatório de Volta Grande, rio Grande - MG/SP. Acta Scientiarum: Biological Sciences. Maringá, v. 25 , n. 1 , p. $79-86$.

GOUlART, M.D. \& CALlisto, M. 2003. Bioindicadores de qualidade de água como ferramenta em estudos de impacto ambiental. Revista FAPAM ano 2, n.1.

GRAÇA, W.J. \& PAVANELLI, C.S. 2007. Peixes da planície de inundação do alto rio Paraná e áreas adjacentes. Ed. Universidade Estadual de Maringá, 240p.

HANSON, L.\& GRIZZLE. 1985. Nitrite-induced predisposition of channel catfish to bacterial diseases Fish Culture, 47, p. 98-101.

KNUDSEN, P.K. \& JENSEN, F.B, 1997. Recovery from nitriteinduced methaemoglobinaemia and potassium balance disturbances in carp. Fish Physiology and Biochemistry. 16: 1-10.

KONIG, R., SUZIN, C.R.H., RESTELLO, R.M. \& HEPP, L.U. 2008. Qualidade das águas de riachos da região norte do Rio Grande do Sul (Brasil) avaliada através de variáveis físicas, químicas e biológicas. Panamjas: Pan-American Journal of Aquatic Sciences 3(1): 84-93.
LAMPARELLI, M.C. 2004. Grau de trofia em corpos d'água do Estado de São Paulo: avaliação dos métodos de monitoramento. 2004. São Paulo: Tese de Doutorado em Ecologia Aplicada. Universidade de São Paulo.

LE-CREN, E.D. 1951. The length-weight relationship and seasonal cycle in gonad weight and condition in the perch (Perca fluviatilis). Journal of Animal. Ecology. 20(2):201-219.

LEMES, E.M. \& V, GARUTTI. 2002. Ecologia da ictiofauna de um córrego de cabeceira da bacia do alto rio Paraná, Brasil. Iheringia, Série Zoológica, Porto Alegre, 92 (3):69-78.

LEMOS, J.R.G., TAVARES-DIAS, M., SALES, R.S.A., NOBRE FILHO, G.R. \& FIM, J.D.I. 2007. Parasitos nas brânquias de Brycon amazonicus (Characidae, Bryconinae) cultivados em canais de igarapé do Turumã-Mirim, estado do Amazonas, Brasil. Acta Scientiarum: Biological Sciences, Maringá, v. 29, n. 2, p. 217-222.

LIMA-JUNIOR, S.E. 2004. A ictiofauna e a qualidade da água em trechos do rio Corumbataí - SP. Instituto de Biociências da Universidade Estadual Paulista Júlio de Mesquita Filho. 2004. 232 p. Tese (Doutorado) Rio Claro, SP.

LIZAMA, M.A.P. \& AMBRÓSIO, A.M. 1999. Relação pesocomprimento e estrutura da população de nove espécies da família Characidae na planície de inundação do alto rio Paraná, Brasil. Revista Brasileira de Zoologia, 16(3): p. 779-788.

LIZAMA, M.A.P \& AMBRÓSIO, A.M. 2002. Condition factor in nine species of fish of the Characidae family in the upper Parana river floodplain, Brazilian Journal of Biology, v.62, Maringá(PR), n.1, p. 113-124.

LUCINDA, P.H.F. 2008. Systematics and biogeography of the genus Phalloceros Eigenmann, 1907 (Cyprinodontiformes: Poeciliidae: Poeciliinae), with the description of twenty-one new species. Neotropical Ichthyology Porto Alegre, v.6, n.2, 2008. Disponível em: http://www.scielo.br/scielo.php?script $=$ sci_arttext\&pid $=$ S167962252008000200001\&lng=en\&nrm=iso Acesso: Outubro de 2013.

MACKERETH, F.J.H., HERON, J. \& TALLING, J.F. 1978. Water Analysis: Some Revised Methods for Limnologists. Fresh Water Biological Association. Scientific Publication. N.36. Titus Wilson \& Son ltd., Kendall. 117p.

OLIVEIRA, A.K. 2006. Composição e distribuição da ictiofauna de tributários do Rio Mogi Guaçu e do Rio Corumbataí, Estado de São Paulo. 2006. Tese de Doutorado, Universidade Federal de São Carlos, São Carlos- SP.

OLIVEIRA, D.C. \& BENNEMANN, S.T. 2005. Ictiofauna, recursos alimentares e relações com as interferências antrópicas em um riacho urbano no sul do Brasil. Biota Neotrop [online]. 2005, v.5, n.1, p. 95-107. Disponível em: <http://www.scielo.br/scielo. php?script $=$ sci_arttext\&pid $=$ S1676-06032005000100011\&lng $=$ en\&nrm=iso $>$. ISSN 1676-0603.

ORSI, M.L., CARVALHO, E.D. \& FORESTI, F. 2004. Biologia populacional de Astyanax altiparanae Garutti \& Britski (Teleostei, Characidae) do Médio Rio Paranapanema, Paraná, Brasil. Revista Brasileira de Zoologia, v. 21, n. 2, p. 207-218.

POMPEU, P.S., ALVES. C.B.M \& CALLISTO, M. 2005. In Press. The effects of urbanization on biodiversity and water quality in the Rio das Velhas basin, Brazil. In Brown, L.R. Gray, R.H. Hughes, R.M. and Meadow, M.R., editors. Effects of urbanization on stream ecosystems. American Fisheries Society, Symposium 47, Bethesda Maryland.

RASHED, M.N. 2001. Monitoring of environmental heavy metals in fish from Nasser Lake. Environ Int. 27(1):27-33.

RÊGO, A.C.L., PINESE, O.P., MAGALHÃES, P.A. \& PINESE, J.F. 2008. Relação peso-comprimento para Prochilodus lineatus (Valenciennes, 1836) e Leporinus friderici (Bloch, 1794) (Characiformes) no reservatório de Nova Ponte - EPDA de Galheiro, rio Araguari, MG. Revista Brasileira de Zoociências, v. 10, n. 1 , p. $13-21$.

ROCHA, M.A., RIBEIRO, E.L., MIZUBUTI, I.Y., SILVA, L.D.F., BOROSKY, J.C. \& RUBIN, K.C.P. 2005. Uso do fator de 
condição alométrico e de fulton na comparação de carpa (Cyprinus carpio), considerando os sexos e idade. Semina: Ciências Agrárias, Londrina, v.26, n.3, p. 429-434. Sciences 29: 217-222.

SCHULZ, U.H. \& MARTINS-JUNIOR, H. 2001. Astyanax fasciatus as bioindicator of water pollution of rio dos Sinos, RS, Brazil. Brazilian Journal of Biology. 61(4): p. 615-622.

SÉ, J.A.S. 1992. O Rio Monjolinho e sua Bacia Hidrográfica como Integradores de Sistemas Ecológicos. 381 p. Dissertação (Mestrado). Escola de Engenharia de São Carlos, Universidade de São Paulo, São Carlos, SP.

SOUZA, A.B. 2011. Avaliação da qualidade ambiental nas nascentes do rio Monjolinho na porção à montante da estação de captação de água do Esparaiado, São Carlos-SP. 182f. Dissertação (Mestrado em Ecologia e Recursos Naturais, Universidade Federal de São Carlos).

STRICKLAND, J.D. \& PARSONS, T.R. 1960. A manual of sea water analysis. Bulletin Fisheries. Research Board of Canada., v. 125, $1-185 p$.

TER BRAAK, C.J.F. \& ŠMILAUER, P. 2002. CANOCO reference manual CanoDraw for Windows user's guide: software for canonical community ordination (version 4.5). - Microcomputer Power IthacaNY, US. 500 pp.
TOLEDO, J.A.P., TALARICO, M., CHINEZ, S.J., AGUDO, E.G. 1983. A aplicação de modelos simplificados para a avaliação do processo da eutrofização em lagos e reservatórios tropicais. Congresso Brasileiro de Engenharia Sanitária e Ambiental. Balneário Camboriú, Santa Catarina.

TUNDISI, J.G., MATSUMURA TUNDISI, J.M, T.M. 2008. Limnologia $1^{\text {a }}$. Ed. Oficina de Textos, São Paulo, 632p.

VALDERRAMA, J.C. 1981. The simultaneous analysis of total nitrogen and phosphorus in natural water. Mar. Chem., v.10, p. 109-122.

VAZZOLER, A.E.A.M. 1996. Biologia da reprodução de peixes teleósteos: teoria e prática. Maringá: Eduem. 169p.

VERANI, J.R. 1980. Controle populacional em cultivo intensivo comparado entre a tilápia do Nilo, Sarotherodon niloticus (Linnaeus, 1757) e o tucunaré comum, Cichla ocellaris Schneider,1801. Aspectos quantitativos. 1980. Dissertação (Mestrado)-Departamento de Ciências Biológicas, Universidade Federal de São Carlos, São Carlos.

WOOTTON, R.J. 1991. Ecology of teleost fishes. Fish and Fisheries Series \#1. Chapman \& Hall. London 404 p.

ZAR, J.H. 2010. Biostatistical analysis. Prentice-Hall, New Jersey 5ed. $944 \mathrm{p}$. 